\title{
Soil organic carbon content and stocks in an age-sequence of Metasequoia glyptostroboides plantations in coastal area, East China
}

\author{
Lei Zhang ${ }^{1, a}$, Peng Zhang ${ }^{1, b}$, Mukui $\mathrm{Yu}^{1, \mathrm{c}}$ and Tonggui $\mathrm{Wu}^{1, \mathrm{~d}^{*}}$ \\ ${ }^{1}$ East China Coastal Forest Ecosystem Long-term Research Station, Research Institute of \\ Subtropical Forestry, Chinese Academy of Forestry, Fuyang, Zhejiang 311400, PR China \\ azhangleiyls@126.com, b972415378@qq.com, ‘yumukui@sina.com, \\ dwutonggui@caf.ac.cn
}

\begin{abstract}
Keywords: SOC content and stocks; physical properties; chemical properties; stand age; coastal Metasequoia glyptostroboides plantations

Abstract. Information on soil organic carbon (SOC) content and stocks is not available in coastal shelter forests, East China, although a large area of forests has been established there in the past 30 years. Dawn Redwood (Metasequoia glyptostroboides) is one of the most commonly tree species for shelter plantation in eastern coasts of China, but it is unknown on the temporal distribution of SOC content and stock in the M. glyptostroboides plantations. In this study, SOC contents and stocks, and soil properties were determined in an age-sequence $(23,27$, and 33 years old) of $M$. glyptostroboides plantations in Shanghai, East China. SOC content and stocks increased gradually with the increasing stand age, and the total SOC stocks in the depth of $0-100 \mathrm{~cm}$ increased by $53.20 \%$ with stand age from 23 to 33 years stand. Meanwhile, SOC showed good relationships with soil physical properties (such as soil particle composition) and chemical properties (such as soil nitrogen and potassium concentrations). Our results indicate that afforestation with $M$. glyptostroboides can promote SOC content and stocks and improve nutrient conditions in coastal lands, and provide data for estimating ecosystem carbon stocks of coastal shelter forests in China.
\end{abstract}

\section{Introduction}

Soil carbon (C) stock has been considered to be impacted by land use and land cover, which leads to changes in soil physical structure and chemical component [1-3]. Afforestation has been recognized to be an important measure to mitigate atmospheric $\mathrm{CO}_{2}$ by sequestering $\mathrm{C}$ in larger biomass, with a longer rotation, and in soils [4-6]. Soil organic C (SOC) stocks accounts for two thirds of the $\mathrm{C}$ stocks in forest ecosystem, and is more stable than that in biomass [7]. However, it is difficult to quantify SOC stocks compared with that in biomass [8,9], because SOC stocks may be affected by many factors, such as forest type, tree species, stand age, climate, and soil physical and chemical properties [2,6,10-13].

Although SOC content or stocks following afforestation and stand age have been widely conducted, the results are diverse. SOC content increases with the stand age in many studies [5,6], while contrary result is also found in early duration after afforestation [7,9]. Therefore, SOC content, especially in surface soil layer, would be affected by the changes of biomass, root, herb and soil physical and chemical characteristic across stand age $[5,14,15]$. However, a majority of studies have found that the SOC content declines firstly, then increases with the stand age increasing $[7,16]$.

The afforestation in coastal saline lands has last for several decades in China, which aims at improving environment and protecting human life, industrial and agricultural production from oceanic disasters [17]. The afforestation area arrives about $4.2 \times 106$ ha in coastal China since 1991 [18], however, SOC stock could not be calculated as a single forest type at national scale, due to less data on SOC content and stocks for coastal forest. Since the 1970s, Metasequoia glyptostroboides, a living fossil in the plant kingdom, has been one of the most commonly tree species for afforestation in coastal lands, East China [17]. For example, the total area of $M$. glyptostroboides plantations reaches $2.1 \times 105$ ha merely in Shanghai, accounting for $31.02 \%$ of the total afforestation area [19]. This seems to profoundly influence soil C stocks, however, little is known about the dynamics of soil $\mathrm{C}$ content and stocks in an age-sequence $M$. glyptostroboides 
forests. Meanwhile, a better knowledge of dynamics of SOC content and stocks for age-sequence $M$. glyptostroboides forests can also supply more correct data for $\mathrm{C}$ stocks statistics in China. In the present study, we determined the SOC content and stocks in M. glyptostroboides plantations with different ages. Our objectives are to (1) investigate the SOC content and stocks in age-sequence of M. glyptostroboides plantations in coastal East China; and (2) clarify relationships between soil physical and chemical properties and SOC content.

\section{Methods and materials}

Experimental site. The field experiment was located in East China Sea Farm, Pudong district, Shanghai, P. R. China $\left(121^{\circ} 52^{\prime}-121^{\circ} 58^{\prime} \mathrm{E}, 30^{\circ} 56^{\prime}-31^{\circ} 00^{\prime} \mathrm{N}\right)$, the east of which is next to East China Sea. The average altitude is about $1-3 \mathrm{~m}$. The climate is subtropical humid monsoon with four distinct seasons, abundant rainfall and ample sunshine. Annual mean temperature is $15.8{ }^{\circ} \mathrm{C}$ and mean precipitation is $1081 \mathrm{~mm}$. The M. glyptostroboides forests were established along land to sea in 1979, 1985 and 1989 successively (with stand ages of 33, 27 and 23 years old, respectively). The structural characteristics of each stand are showed in Table 1.

Table 1 Basic stand structural characteristics of three Metasequoia glyptostroboides forests

\begin{tabular}{ccccc}
\hline $\begin{array}{c}\text { Stand age } \\
\text { [year] }\end{array}$ & $\begin{array}{c}\text { Height under branch } \\
{[\mathrm{m}]}\end{array}$ & $\begin{array}{c}\text { Mean height } \\
{[\mathrm{m}]}\end{array}$ & $\begin{array}{c}\text { DBH } \\
{[\mathrm{cm}]}\end{array}$ & $\begin{array}{c}\text { Planting spacing } \\
{[\mathrm{m}]}\end{array}$ \\
\hline 23 & 8.12 & 18.32 & 22.25 & $3 \times 4$ \\
27 & 9.31 & 19.29 & 23.36 & $3 \times 4$ \\
33 & 11.80 & 20.15 & 25.26 & $3 \times 4$ \\
\hline
\end{tabular}

Methods and Measurements. Three plots of $20 \mathrm{~m} \times 20 \mathrm{~m}$ were established in each $M$. glyptostroboides plantation stands in late August, 2012, respectively. In each plot, six soil cores were randomly collected at 0-20, 20-40, 40-60 and 60-100 cm layers under the help of soil auger ( $5 \mathrm{~cm}$ in diameter), following removal of understory plants and surface litter, and thoroughly mixed to homogenize a sample. Meanwhile, six samples were also collected using volumetric rings (100 $\mathrm{cm}^{3}$ ) from each layer and each plot to determine bulk density.

SOC content was determined by the potassium dichromate oxidation method [20]. SOC stocks were calculated by SOC content, bulk density and soil depth.

$$
\text { SOC stock }=\sum_{i=1}^{n}\left(C_{i} \times d_{i} \times D_{i}\right) \text {. }
$$

Where, $\mathrm{i}$ is soil layer, $\mathrm{Ci}$ is SOC content, di is soil bulk density, Di is soil depth.

The physical properties, such as soil particle composition, bulk density were chosen in this study. The soil particle composition was measured with Malvern Mastersizer 2000: clay $(<2 \mu \mathrm{m})$, silt $(2-20 \mu \mathrm{m})$ and sand $(>20 \mu \mathrm{m})$ particles were divided based on the particle size. Bulk density was measured and calculated by the cutting ring method.

The chemical properties, such as total nitrogen $(\mathrm{N})$, total phosphorus $(\mathrm{P})$, total potassium $(\mathrm{K})$, hydrolyzable $\mathrm{N}$, available $\mathrm{P}$ and available $\mathrm{K}$, were also chosen. Salt content was measured by DDSJ-308A conductivity meter. Hydrolyzable $\mathrm{N}$, available $\mathrm{P}$ and available $\mathrm{K}$ were measured respectively by the alkaline hydrolysis diffusion method, hydrochloric acid extraction Mo-Sb anticolorimetric method and ammonium acetate extraction flame spectrophotometric method [20]. Catalase activity was measured using $\mathrm{H}_{2} \mathrm{O}_{2}$ as a substrate, incubated for $20 \mathrm{~min}$ and the filtrate was titrated with $0.1 \mathrm{~mol} \mathrm{~L}^{-1} \mathrm{KMnO}_{4}$. Catalase activity is expressed as mmol $\mathrm{KMnO}_{4}$ consumed $\mathrm{g}^{-1} \mathrm{~h}^{-1}$.

Statistical analyses. General linear model (GLM) and analysis of variance (ANOVA) were used to analyze the effect of stand age and soil layer on SOC content and stocks. Scatter plots were used to visualize the relationships between SOC contents and soil properties, based on which appropriate 
regression equations were developed using regression analysis. All statistical analyses were conducted using SPSS software (SPSS Inc, 2008).

\section{Results}

SOC contents and stocks of age sequence $M$. glyptostroboides forests. Stand age $(P=0.000)$ and soil layer $(P=0.000)$ had significant effects on SOC contents, whereas their interactions $(P=$ 0.467 ) did not significantly (Table 2). Except 0-20 cm layer, SOC content in all soil layers were significantly higher in 33 years old stand than those in 27 and 23 years old stands $(P<0.05)$. SOC contents decreased significantly with the increase of soil depth, and SOC content in 0-20 cm layers were higher than those in other layers for each stand $(P<0.05)$.

Table 2 SOC contents $\left(\mathrm{mg} \mathrm{g}^{-1}\right)$ in three Metasequoia glyptostroboides stands. Values in parentheses are standard errors of the means $(n=3)$. Means with different uppercase (A and B) and lowercase (a and b) letters are significantly different between soil layers for each Metasequoia glyptostroboides stand and between Metasequoia glyptostroboides stands for each soil layer $(P<0.05)$, respectively. Values with the various letter in each line are significantly different $(p<0.05)$.

\begin{tabular}{llll}
\hline $\begin{array}{c}\text { Soil layer } \\
{[\mathrm{cm}]}\end{array}$ & \multicolumn{3}{c}{\begin{tabular}{c} 
Stand age [years] \\
\multicolumn{1}{c}{23}
\end{tabular}} \\
\hline $0-20$ & $10.23 \pm 0.96 \mathrm{a}$ & $12.34 \pm 1.00 \mathrm{a}$ & $14.29 \pm 0.96 \mathrm{a}$ \\
$20-40$ & $3.20 \pm 0.33 \mathrm{~B} \mathrm{~b}$ & $4.72 \pm 0.62 \mathrm{~B} \mathrm{~b}$ & $7.12 \pm 0.54 \mathrm{~A} \mathrm{~b}$ \\
$40-60$ & $3.65 \pm 0.52 \mathrm{~B} \mathrm{~b}$ & $3.40 \pm 0.45 \mathrm{~B} \mathrm{~b}$ & $6.28 \pm 0.38 \mathrm{~A} \mathrm{~b}$ \\
$60-100$ & $4.85 \pm 0.56 \mathrm{AB} \mathrm{b}$ & $3.97 \pm 0.36 \mathrm{~B} \mathrm{~b}$ & $5.61 \pm 0.16 \mathrm{~A} \mathrm{~b}$ \\
\hline
\end{tabular}

SOC stocks also increased significantly with the increase of stand age for each soil layer, as well as for the sum of $0-100 \mathrm{~cm}(P<0.05$, Fig. 1). The sum of SOC stocks in 33 years old stand $\left(103.27 \pm 8.10 \mathrm{~g} \mathrm{~cm}^{-2}\right)$ was increased by $53.20 \%$ compared with that in 23 years old stand.

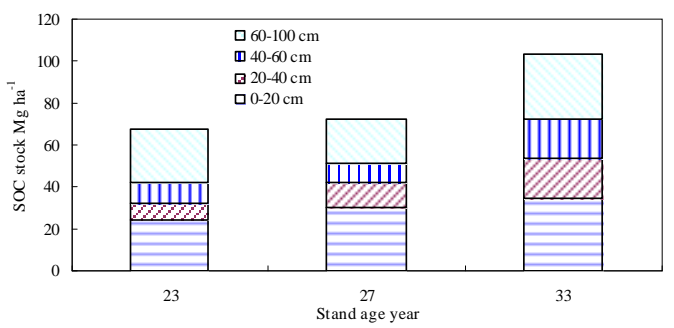

Fig. 1 SOC stocks in different soil layers for three aged Metasequoia glyptostroboides stands

Relationships between SOC content and soil properties. The SOC content was significant positively correlated with clay and silt contents $(P<0.05$, Fig. $2 \mathrm{a}, 2 \mathrm{~b})$, and negatively correlated with sand content $(P<0.05$, Fig. $2 \mathrm{c})$, except in $0-20 \mathrm{~cm}$ soil layer.

The SOC content was positively correlated with total $\mathrm{N}$, hydrolyzable $\mathrm{N}$, available $\mathrm{K}$ contents, $\mathrm{N}: \mathrm{P}$, and $\mathrm{N}: \mathrm{K}(P<0.05$, Fig. 3a-e).
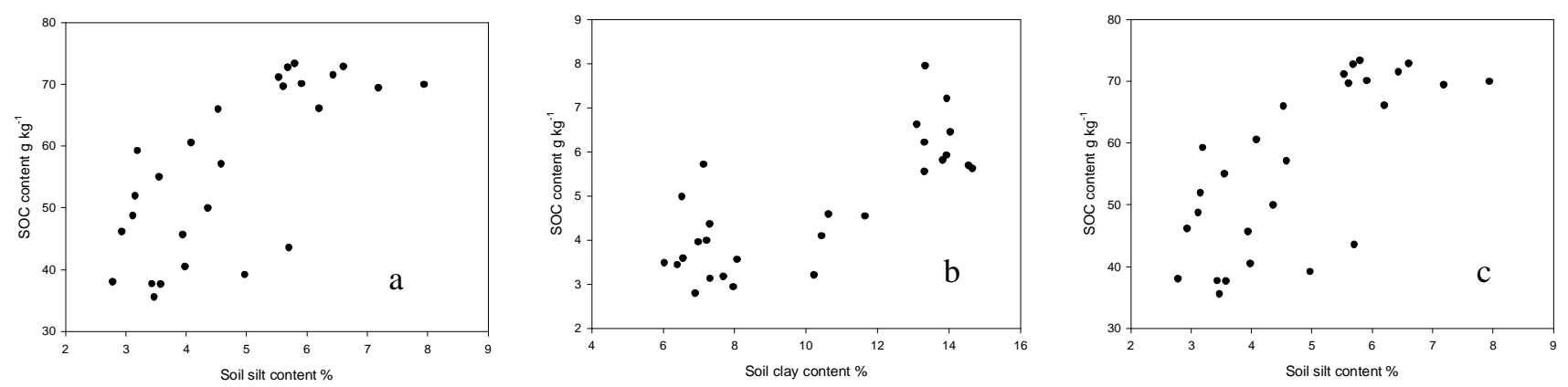

Fig. 2 Relationships between SOC and soil particle composition. Linear fit for (a) SOC content and soil clay content $\left(R^{2}=0.776, P=0.000\right)$, (b) SOC content and soil sand content $\left(R^{2}=0.741, P=0.000\right)$, and (c) SOC content and soil silt content $\left(R^{2}=0.489, P=0.000\right)$. 


\section{Discussion}

In our study, both SOC content and stocks increased significantly with stand age increasing, which is consistent with the results in most studies [5,6]. The diameter of breast height (DBH) and height $(\mathrm{H})$ increased with the increasing of $M$. glyptostroboides stand age (Table 1), and the crown density also increased, which induced the increase of competition among individuals in the stand. Self pruning and even self thinning would appear, for example, the height under branch (HUB) was higher in 33 years old stand (Table 1), and induced more litter quantity [21], which produced more inputs of SOC in older stand. In addition, catalase activity, indicating microbial quantity and activity in soil [22], was higher in 33 years old stand than that in 27 and 23 years old stands (Fig. 4). Microbial biomass and activity of catalse are close related to SOC content [23].
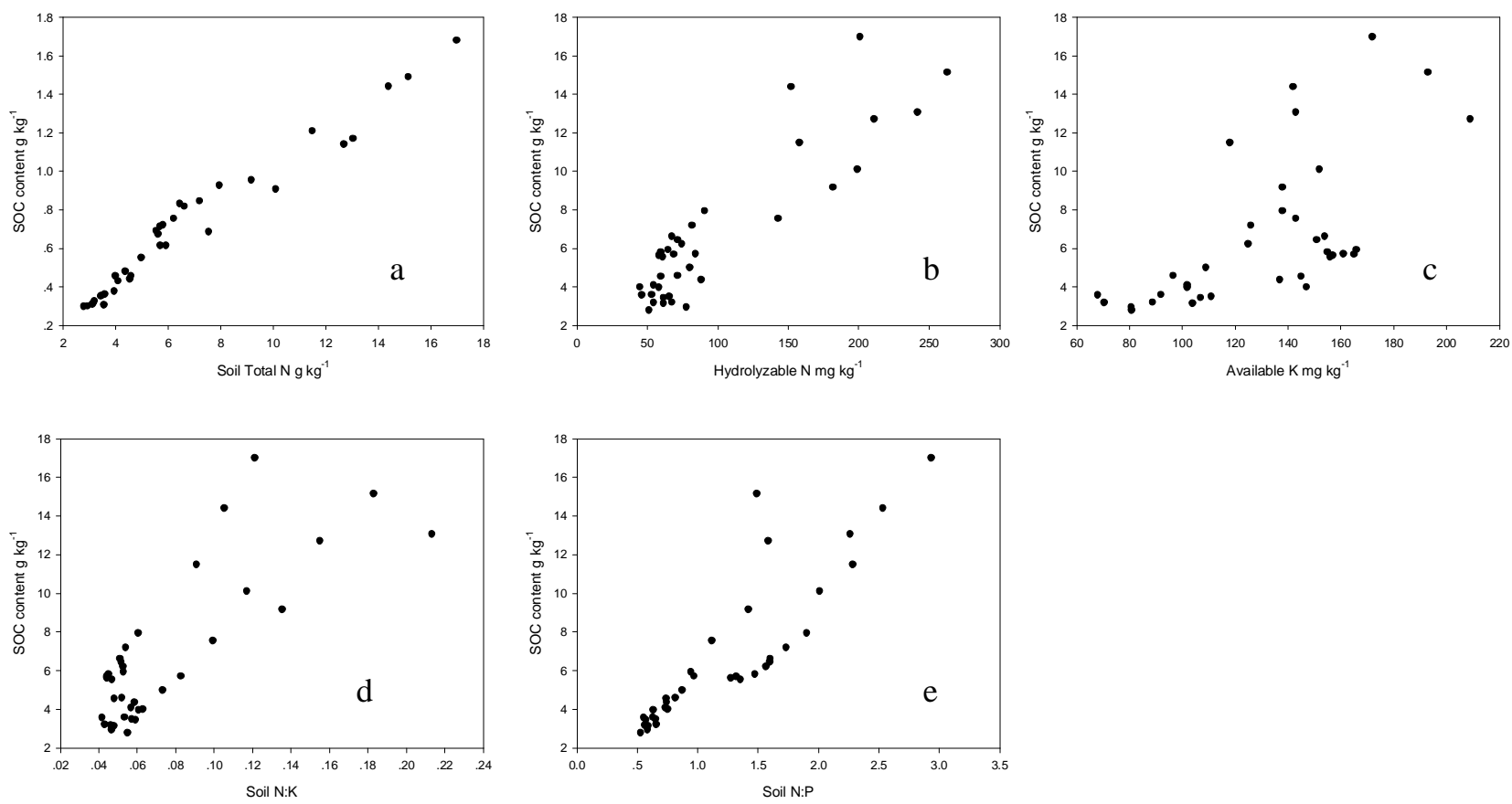

Fig. 3 Relationships between SOC and soil chemical properties. Linear fit for (a) SOC content and soil N content $\left(R^{2}=0.805, P=0.000\right)$. (b) SOC content and soil hydrolyzable N $\left(R^{2}=0.417, P=0.000\right)$, (c) SOC content and soil available K, $\left(R^{2}=0.957, P=0.000\right)$, (d) SOC content and soil $\mathrm{N}: \mathrm{K}\left(R^{2}=0.777, P=0.000\right)$, (e) SOC content and soil $\mathrm{N}: \mathrm{P}\left(R^{2}=0.662, P=0.000\right)$.

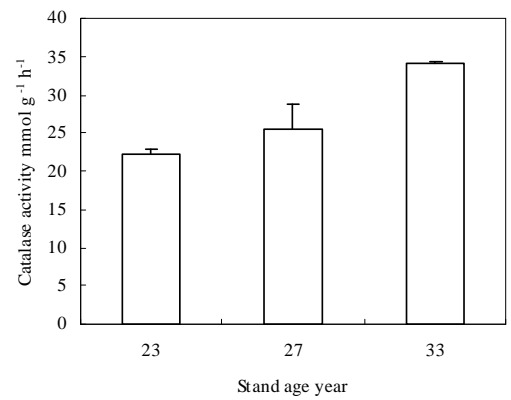

Fig. 4 Soil catalase activity in three aged Metasequoia glyptostroboides stands

Surface SOC content is highly variable [24], which is impacted strongly by litter decomposition and root exudates, secondary metabolites, and root decrepitude and death [13,25,26]. Moreover, the effects of litter and root on SOC become weak in deeper soil layer due to the decrease of litter transference and root quantity, and SOC decreases with the increase of soil depth [13]. In the present study, SOC content in the surface soil layer $(0-20 \mathrm{~cm})$ was significantly larger than any other soil layers. Similarly, the proportion for SOC stock was mainly stored in the layer of 0-20 cm.

Soil texture is one of the main factors affecting on soil $\mathrm{C}$ dynamics, in spite that the causal relationships are not completely known [27,28]. For example, soil $\mathrm{C}$ content is usually closely 
correlated with soil particle composition [29,30]. Soil particle composition is relatively stable, while it might change with afforestation and stand age [14,31], for example, soil clay content would increase and soil sand content would decrease with the stand age increasing, due to soil mineral weathering and biochemical effect of microorganism or plant root [32]. Meanwhile, the amount and stability of C in clay and silt is greater than in sand soil [28]. In our study, SOC content also showed same response to soil particle composition, i.e., it was positively related to soil clay content, and negatively to soil sand content.

SOC content, including dissolved organic carbon, microbial biomass carbon, is found to be well correlated to total $\mathrm{N}$ and available $\mathrm{N}$ in many studies [6,31]. 24 portions of $\mathrm{C}$ are consumed when microbes assimilate 1 portion of $\mathrm{N}$, indicating that the effectiveness of mineral $\mathrm{N}$ in soil directly is controlled by the decomposition rate of SOC $[33,34]$. Available N, K could accelerate the growth of plants and simultaneously provide sufficient nutrient for the robust root system of plants, increasing the residual of plant in the soil, and that increasing SOC [35]. In this study, we also found a positive linear correlation between SOC content and soluble K, which might be relevant with soluble K released by the soil parent material with increasing rate of weathering [36]. Meanwhile, soil $\mathrm{P}$ contents, including available $\mathrm{P}$ and total $\mathrm{P}$ contents, showed weak correlations to SOC content in this study. It is well known that soil P is the key limited nutrient element for plant growth in coastal area [37].

Table 3 SOC stocks for Metasequoia glyptostroboides stands in this study, for other similar tree species stands, and the average SOC stocks for forests in China and globe.

\begin{tabular}{|c|c|c|c|c|c|}
\hline Site & Species & $\begin{array}{c}\text { Age } \\
\text { [years] }\end{array}$ & $\begin{array}{l}\text { Soil depth } \\
{[\mathrm{cm}]}\end{array}$ & $\begin{array}{l}\text { SOC stock } \\
{\left[\mathrm{Mg} \mathrm{ha}^{-1}\right]}\end{array}$ & Reference \\
\hline \multirow{6}{*}{$\begin{array}{l}\text { Shanghai, coastal } \\
\text { China }\end{array}$} & \multirow{6}{*}{$\begin{array}{l}\text { Metasequoia } \\
\text { glyptostroboides }\end{array}$} & \multirow{2}{*}{23} & 40 & 32.26 & \multirow{6}{*}{ This study } \\
\hline & & & 100 & 67.40 & \\
\hline & & \multirow{2}{*}{27} & 40 & 42.17 & \\
\hline & & & 100 & 72.23 & \\
\hline & & \multirow{2}{*}{33} & 40 & 53.97 & \\
\hline & & & 100 & 103.27 & \\
\hline Huitong, Hunan & Chinese fir & \multirow{2}{*}{22} & \multirow{2}{*}{100} & \multirow{2}{*}{85.27} & \multirow{2}{*}{ Niu et al., 2009} \\
\hline Province, China & Cunninghamia lanceolata & & & & \\
\hline \multirow{2}{*}{ Beijing mountain area } & Chinese pine & \multirow{2}{*}{25} & \multirow{2}{*}{40} & \multirow{2}{*}{68.53} & \multirow{2}{*}{ Cao et al., 2011} \\
\hline & Pinus armandii & & & & \\
\hline \multirow{2}{*}{ Beijing mountain area } & Oriental arborvitae & \multirow{2}{*}{32} & \multirow{2}{*}{40} & \multirow{2}{*}{57.75} & \multirow{2}{*}{ Cao et al., 2011} \\
\hline & Platycladus orientalis & & & & \\
\hline \multirow{2}{*}{ South Ontario, Canada } & White pine & \multirow{2}{*}{30} & \multirow{2}{*}{55} & \multirow{2}{*}{30.00} & Peichl and Arain, \\
\hline & Pinus monticola & & & & 2006 \\
\hline Southeast Queensland, & Hoop pine & 25 & 100 & 188.9 & Richards et al., \\
\hline Australia & Araucaria cunninghamii & 34 & 100 & 175.9 & 2007 \\
\hline \multirow{2}{*}{ Shanghai } & Tidal area & - & - & 13.8 & \multirow{2}{*}{ Wang, 2013} \\
\hline & Average for all forest soil & - & - & 31.85 & \\
\hline \multirow{2}{*}{ China } & Average for all forest soil & - & - & 107.8 & Liu et al., 2011 \\
\hline & Average for plantation soil & - & - & 107.1 & Liu et al., 2011 \\
\hline Global & Average for all forest soil & - & - & 72.3 & FAO, 2011 \\
\hline
\end{tabular}

- represents no data. 
SOC stocks in 23 and 27 years old $M$. glyptostroboides plantations were obviously higher than the average SOC stocks in other forests and in tidal field in Shanghai [38](31.85, $13.8 \mathrm{Mg} \mathrm{ha}^{-1}$, respectively, in Table 3), similar to the average SOC stocks of global forests [39](72.3 $\left.\mathrm{Mg} \mathrm{ha}^{-1}\right)$, but far lower than the average SOC stocks of natural forests and planted forests in China [40](107.8 and 107.1 $\mathrm{Mg} \mathrm{ha}^{-1}$, respectively). SOC stock in 33 years old M. glyptostroboides plantation was higher than the average SOC stock of global forests, and similar to the average SOC stocks of natural forests and planted forests in China (Table 3). Compared with other similar tree species, SOC stocks in 23 and 27 years old M. glyptostroboides plantations were far lower than those in Chinese fir (Cunninghaia lanceolata), Chinese pine (Pinus armandii) and Hoop pine (Araucaria cunninghamii) plantations, in terms of similar age and soil depth [41-43](in Table 3). SOC stocks in 33 years old M. glyptostroboides plantation was higher than those in Oriental arborvitae (Platycladus orientalis) and white pine (Pinus monticola), but far lower than in Hoop pine [12,42,43]. In sum, the SOC stock of $0-100 \mathrm{~cm}$ soil depth in M. glyptostroboides stands was relatively low. First, SOC content in tidal field before afforestation (for example, only $5.30 \mathrm{~g} \mathrm{~kg}^{-1}$ ) is far lower than that in agricultural land and abandoned land in the same area $\left(11.10,14.47 \mathrm{~g} \mathrm{~kg}^{-1}\right.$, respectively) [3]. Second, the study site was located in the edge of north subtropical monsoon climate area, which had high litter decomposition rate and soil respiration rate due to the high temperature and humidity, accelerating decomposition speed of organic substance and reducing the content of SOC in soil [44]. While, the SOC stocks approaches the average of natural forests in China after 33 years of afforestation for $M$. glyptostroboides, which shows a significant $\mathrm{C}$ sequestration for afforestation in coastal China.

\section{Conclusion}

SOC contents and stocks, especially for deeper layer $(20-100 \mathrm{~cm})$, increased with the stand development for M. glyptostroboides plantations in coastal East China, being an increase of 53.20\% from 23 old years stand to 33 years old stand. Moreover, soil physical (such as soil particle composition) and chemical properties (such as soil nitrogen and potassium) showed well correlations to SOC content. Our results showed SOC content, stocks and nutrient conditions can be significantly promoted by afforestation in the coastal area of China.

\section{Acknowledgement}

The project was supported by the Fundamental Research Funds for the Central Non-profit Research Institution of CAF (No. CAFYBB2014ZD002), the National Natural Science Foundation of China (No. 31200533), the Program for Zhejiang Leading Team of S \& T Innovation (No. 2011R50027), and the Research Institute of Sub-tropical Forestry Fund (No. RISF61323).

\section{References}

[1] D.J. Ross, K.R. Tate, N.A. Scott, C.W. Feltham, Land-use change: effects on soil carbon, nitrogen and phosphorus pools and fluxes in three adjacent ecosystems, Soil Biol. Biochem. 31 (1999) 803-813.

[2] S.J. Morris, S. Bohm, S.H.A.W.E.L. Haile-Mariams, E.A Paul, Evaluation of carbon accrual in afforested agricultural soils, Global Change Biol. 13 (2007) 1145-1156.

[3] D. Wang, B. Wang, X. Niu, Forest carbon sequestration in China and its benefits, Scandinavian J. Forest Res. 29 (2014) 51-59.

[4] D. Richter, D. Markewitz, S. Trumbore, C. Wells, Rapid accumulation and turnover of soil carbon in a re-estabilishing forest, Nature 400 (1999) 56-58. 
[5] H. Smal, M. Olszewska, The effect of afforestation with Scots pine (Pinus silvestris L.) of sandy post-arable soils on their selected properties. II. Reaction, carbon, nitrogen and phosphorus, Plant Soil. 305 (2008) 171-187.

[6] S.T Berthrong, E.G Jobbágy, R.B. Jackson, A global meta-analysis of soil exchangeable cations, pH, carbon, and nitrogen with afforestation, Ecol. Appl. 19 (2009) 2228-2241.

[7] R. Mao, D.H. Zeng, Y.L. Hu, L.J. Li, D. Yang, Soil organic carbon and nitrogen stocks in an age-sequence of poplar stands planted on marginal agricultural land in Northeast China, Plant Soil. 332 (2010) 277-287.

[8] T. Teklay, S.X Chang, Temporal changes in soil carbon and nitrogen storage in a hybrid poplar chronosequence in northern Alberta, Geoderma. 144 (2008) 613-619.

[9] J. Laganiere, D.A. Angers, D. Pare, Carbon accumulation in agricultural soils after afforestation: a meta-analysis, Global Change Biol. 16 (2010) 439-453.

[10] K.I. Paul, P.J. Polglase, J.G. Nyakuengama, P.K. Khanna, Change in soil carbon following afforestation, Forest Ecol. Manag. 168 (2002) 241-257.

[11] L.B. Guo, R.M. Gifford, Soil carbon stocks and land use change: a meta analysis, Global Change Biol. 8 (2002) 345-360.

[12]M. Peichl, M.A. Arain, Above-and belowground ecosystem biomass and carbon pools in an age-sequence of temperate pine plantation forests, Agr. Forest Meteorol. 140 (2006) 51-63.

[13] J.L. Mora, J.A. Guerra, C.M. Armas-Herrera, C.D. Arbelo, A. Rodriguez-Rodriguez, Storage and depth distribution of organic carbon in volcanic soils as affected by environmental and pedological factors, Catena. 123 (2014) 163-175.

[14]J. Six, P. Callewaert, S. Lenders, S. De Gryze, S.J. Morris, E.G. Gregorich, K. Paustian, Measuring and understanding carbon storage in afforested soils by physical fractionation, Soil Sci. Soc. Am. J. 66 (2002) 1981-1987.

[15]N.J. Noh, Y.H. Son, S.K. Lee, K.W. Seo, S.J. Heo, M.J. Yi, P.S. Park, R.H. Kim, Y.M. Son, K.H. Lee, Carbon and nitrogen storage in an age-sequence of Pinus densiflora stands in Korea, Sci. China (Life Sci.). 53 (2010) 822-830.

[16]X. Chen, L.B. Hutley, D. Eamus, Soil organic carbon content at a range of north Australian tropical savannas with contrasting site histories, Plant Soil. 268 (2005) 161-171.

[17]T. Wu, M. Yu, G. Wang, Z. Wang, X. Duan, Y. Dong, X. Cheng, Effects of stand structure on wind speed reduction in a Metasewuoia glyptostroboides shelterbelt, Agroforest, Syst. 87 (2013) 251-257.

[18]Information on http://www.forestry.gov.cn/portal/main/s/241/content-475117.html

[19] Li, Y. The effect of coastal shelter-forest on soil biological activity and wind-break potency in Shanghai, Master's Theses, Nanjing Forestry University, Nanjing, China, 2011.(in Chinese with English abstract)

[20] S.D. Bao, Agricultural and chemical analysis of soils, China Agricultural, Beijing, China, 2000. (in Chinese) 
[21] Y.Inagaki, S. Miura, A. Kohzu, Effects of forest type and stand age on litterfall quality and soil N dynamics in Shikoku district, southern Japan, Forest Ecol. Manag. 202 (2004) 107-117.

[22] J.D. Liao, T.W. Boutton, Soil microbial biomass response to woody plant invasion of grassland, Soil Biol. Biochem. 40 (2008) 1207-1216.

[23] A.P. Smith, E. Marin-Spiotta, M.A. de Graaff, T.C. Balser, Microbial community structure varies across soil organic matter aggregate pools during tropical land cover change, Soil Biol. Biochem. 77 (2014) 292-303.

[24]H. Wang, J.D. Cornell, C.A.S. Hall, D.P. Marley, Spatial and seasonal dynamics of surface soil carbon in the Luquillo experimental forest, Puerto Rico, Ecol. Model. 147 (2002) 105-122.

[25]Y. Ma, T.R. Filley, K. Szlavecz, M.K. McCormick, Controls on wood and leaf litter incorporation into soil fractions in forests at different successional stages, Soil Biol. Biochem. 69 (2014) 212-222.

[26] J. Leppalammi-Kujansuu, L. Aro, M. Salemaa, K. Hansson, D.B. Kleja, H. Helmisaari, Fine root longevity and carbon input into soil from below- and aboveground litter in climatically contrasting forests, Forest Ecol. Manag. 326 (2014) 79-90.

[27]A.J. Franzluebbers, R.L.Haney, F.M. Hons, D.A. Zuberer, Active fractions of organic matter in soils with different texture, Soil Biol. Biochem. 28 (1996) 1367-1372.

[28] T. Keller, I. Hakansson, Estimation of reference bulk density from soil particle size distribution and soil organic matter content, Geoderma. 154 (2010) 398-406.

[29]A.R. Quiroga, D.E. Buschiazzo, N. Peinemann, Soil organic matter particle size fractions in soils of the semiarid Argentinean Pampas, Soil Sci. 161 (1996)104-108.

[30] J. Hassink, The capacity of soils to preserve organic $\mathrm{C}$ and $\mathrm{N}$ by their association with clay and silt particles, Plant Soil. 191 (1997) 77-87.

[31] S.Y. Korkanc, Effects of afforestation on soil organic carbon and other soil properties, Catena. 123 (2014) 62-69.

[32] S. Imhoff, A.P. Silva, D. Fallow, Susceptibility to compaction, load support capacity, and soil compressibility of hapludox, Soil Sci. Soc. Am. J. 68 (2004) 17-24.

[33]L. Zhou, B.G. Li, G.S. Zhou, Advances in controlling factors of soil organic carbon, Advances in Earth Science. 20 (2005) 99-105.

[34]Q.K. Wang, S.L. Wang, Z.W. Feng, Y. Huang, Active soil organic matter and its relationship with soil quality, Acta Ecologica Sinica. 25 (2005) 513-519.

[35]C.X. Zhang, M.D. Hao, B.C Xie, Effect of Application Amounts of Different Chemical Fertilizers on Soil Carbon Pool, Chinese Journal of Soil Science. 37 (2006) 861-864.

[36] Y. Lucas, The role of plants in controlling rates and products of weathering: importance of biological pumping, Annu. Rev. Earth Pl. Sci. 29 (2001) 135-163.

[37]W. Han, J. Fang, D. Guo, Y. Zhang, Leaf nitrogen and phosphorus stoichiometry across 753 terrestrial plant species in China, New Phytol. 168 (2005) 377-385.

[38]Z. Wang, X. Cui, S. Yin, G. Shen, Y. Han, C. Liu, Characteristics of carbon storage in Shanghai's urban forest, Chinese Sci. Bull. 58 (2013) 1130-1138. 
[39]Food and Agriculture Organization of the United Nations (FAO), Global Forest Resources Assessment, 2010.

[40] S. Liu, H. Wang, J. Luan, A review of research progress and future prospective of forest carbon stock and soil carbon process in China, Acta Ecol. Sinica. 31 (2011) 5437-5448. (in Chinese with English abstract)

[41]D. Niu, S. Wang, Z. Ouyang, Comparisons of carbon storages in Cunninghamia lanceolata and Michelia macclurei plantations during a 22-year period in southern China, J. Environ. Sci. 21 (2009) 801-805.

[42]J.X. Cao, Above- and belowground carbon pools in different ages of Chinese Pine and Oriental Arborvitae plantation forests in northern mountain areas of Beijing, Master's Theses, Beijing Forestry University. Beijing, China, 2011. (in Chinese with English abstract)

[43] A.E. Richards, R.C. Dalal, S. Schmidt, Soil carbon turnover and sequestration in native subtropical tree plantations, Soil Biol. Biochem. 39 (2007) 2078-2090.

[44]W. Xiao, X. Ge, L. Zeng, Z. Huang, J. Lei, B. Zhou, M. Li, Rates of litter decomposition and soil respiration in relation to soil temperature and water in different-aged Pinus massoniana forests in the three gorges reservoir area, China, Plos One. 9 (2014) e101890. 